Article

\title{
Lessons Learned from Establishing the Energy-Informatics Business Model: Case of a German Energy Company
}

\author{
Matti Grosse ${ }^{1,2, * \mathbb{D}}$, Hendrik Send ${ }^{2,3}$ and Thomas Schildhauer ${ }^{2,4}$ \\ 1 Faculty of Economics and Management, Technical University Berlin, 10587 Berlin, Germany \\ 2 Alexander von Humboldt Institute for Internet and Society, 10117 Berlin, Germany; send@hiig.de (H.S.); \\ schildhauer@hiig.de (T.S.) \\ 3 Department of Economics, Anhalt University of Applied Science, 06406 Bernburg, Germany \\ 4 Institute of Electronic Business, Berlin University of the Arts, 12165 Berlin, Germany \\ * Correspondence: m.grosse@tu-berlin.de; Tel.: +49-30-314-76862
}

Received: 7 January 2019; Accepted: 5 February 2019; Published: 7 February 2019

\begin{abstract}
Energy and utilities companies find themselves in a paradoxical situation in which their traditional business models are losing profitability, and they must advocate energy efficiency and climate-protection goals, and thus encourage their customers to save energy. As a result, they must partially cannibalize their business models and experiment with new models and techniques. Energy Informatics (EI) offers promising business opportunities that alleviate the concerns of energy companies about traditional revenue streams. However, recent discussions on this issue lack proof of concept and success determinants. This business case study fills this gap by describing the journey of German energy company Energiequelle, which established a sustainable business model based on EI. On the basis of our interview data, we analyzed Energiequelle's EI strategy and stakeholder management and present six lessons learned. We believe that our practice-oriented research provides profound insight, especially to high-level executives and policymakers.
\end{abstract}

Keywords: Energy Informatics; sustainable business model; stakeholder management; small medium enterprise; social challenges

\section{Introduction}

Globally, energy companies are at a crossroads. Limited fossil resources, safety threats related to nuclear-power generation, and internationally established climate-protection goals force stakeholders in the energy sector to question energy supply and consumption [1,2]. According to international experts, energy markets in 2050 will be dominated by renewables, be organized on the basis of decentralized power generation, have empowered consumers who play an active role in energy production, and reshape industry structure and business models [3-5].

To date, most energy companies still focus on optimizing their existing traditional business models, and they have defended their current state mostly by expanding to adjacent fields of business. However, the abovementioned trends have significant implications for the energy industry and power-plant operators. They will eventually be forced to shut down profitable nuclear and coal-fired power stations because a sustainable energy system based on renewable sources and zero marginal costs of production will replace them [6,7]. Therefore, the business models of many energy producers would be disrupted. Utilities will face increasing competition from innovative new market actors and, ironically, former customers now using "behind-the-meter" on-site generation sources [5,8]. That successful energy companies are concerned about traditional revenue streams is not surprising [9]. In addition, technical issues such as system stability, secure supply, grid management, and storage opportunities all require 
special consideration in an energy system that largely depends on the fluctuations of solar and wind power and includes millions of production and consumption entities.

Recently, Energy Informatics (EI) has entered the discussion, and it promises a holistic energy solution that considers the many requirements of future energy systems [10]. According to the EI framework, three types of technology constitute an intelligent energy-management system: flow networks, sensor networks, and sensitized objects [11]. An overarching information system (IS) brings these various elements together and forms an integrated solution. In this way, EI gains in efficiency in the energy demand and supply system. Implementing EI requires a certain degree of intelligence that the IS must contribute [12]. Key functionalities typically include collecting and transmitting data between networks and objects, supplying relevant information, and managing interdependencies between major components.

These systems are useful for several entities: critical services (hospitals, military, or intelligence installations), commercial and industrial users (research-and-development centers, financial institutions, and server farms), and other areas of application (communities and utilities, health and educational campuses, and smart cities). EI systems are particularly relevant when customers of energy companies demand high reliability, security, and quality supply [13]. In this context, demand-response management (DRM) gives energy suppliers more opportunities to control customers' consumption patterns, and thereby generate additional revenue.

With decentrally managed energy systems, energy companies can sell solutions that ensure a secure supply through local demand and supply management, and potentially decrease energy costs by avoiding peak energy prices and investing less in peak capacity. By implementing decentrally managed energy systems, energy companies can also avoid negative stock-market prices at times of low demand, reduce business dependency on fossil sources such as oil and gas, and contribute to climate-protection goals and decarbonization. Analysts and experts are confident that commercial-scale solutions (smaller than 10 megawatts) can reduce outage times by more than $98 \%$, reduce $\mathrm{CO}_{2}$ emissions by more than $20 \%$, and improve energy efficiency by at least $20 \%$ [14].

What is missing in terms of broad adoption dynamics is a better understanding of how EI could be a way for energy companies to proceed [15]. This understanding includes both technical aspects (e.g., feasibility and application fields) and monetary aspects (e.g., business-model opportunities and revenue streams) [16]. Energy companies are always concerned because consumers and prosumers are gaining more control of energy systems, consequently affecting these companies' revenue streams [17]. Therefore, we need to define new business strategies to help secure grid control and profits. Further, research on energy systems has mainly focused on the technical issues of such systems, but has omitted the social dimension [18]. However, when implementing such systems in real-life settings, they clearly become technosocial; that is, their value is embedded in the interaction between human beings and the system $[19,20]$. Users face both issues of social acceptance of energy systems, and behavioral changes that come with the system [21-23].

In this business case study, we describe how German energy company Energiequelle applied $\mathrm{EI}$ in the community of Feldheim (80 km south of Berlin, Germany). We provide insights into three specific issues: (1) how Energiequelle turned their business strategy toward EI to sustain innovation in the context of energy transition and the changing allocation of market power, (2) how the use of IS in grid management supported Energiequelle's strategy to increase energy efficiency and implement a profitable business solution, and (3) how intelligent stakeholder management affects energy companies while implementing and running an EI system. On the basis of interviews with our case company Energiequelle, key stakeholders in the Feldheim project, and secondary data, we describe the journey of Energiequelle in Feldheim and present six lessons learned from establishing the EI business model. These learnings are especially relevant for chief executive officers (CEOs) and chief business development officers (CBDOs) of energy companies and policymakers. We conclude our work by summarizing the most critical aspects and presenting the limitations of our study. Before describing the case and presenting the setting of the discussed business case, we start by providing an overview 
of the most relevant theoretical concepts that help to understand Energiequelle's strategic approach in Feldheim.

\section{Theoretical background}

\subsection{Business Models}

A business model provides a structured, complexity-reduced, and holistic perspective on how a company conducts business and enables managers to take a comprehensive and user-centric look at a company's activities [24,25]. Analyzing the business model of a firm coincides with understanding the business' architecture and logic [24,26]. Furthermore, the business model may be the "starting point for innovation strategies" [27]. The results of such initiatives can be the creation of an entirely new business strategy or the reconfiguration of the existing model. In both cases, management needs to establish value-creation and -capture mechanisms [28,29]. This change is called business-model innovation when the reconfiguration of the business model is significantly different from the company's existing business model $[28,30]$.

The previous literature distinguishes between static and dynamic views [31]. Whereas the static perspective covers constitutional elements of the business model, the dynamic view describes the evolution of the business model over time. Refinement and evolution processes usually imply challenges such as consistency issues, dissonances, or coupling obstacles [30-32]. Therefore, business-model innovation in the energy sector is accompanied by a series of specific barriers, aside from the general challenges of a business-model development process. These barriers include the consideration of sustainability, which is related to the content of the business models, the orchestration of an innovation ecosystem with regard to codependencies, and dealing with the major role of public policies [33].

\subsection{Energy Informatics}

According to the EI framework, three types of technology constitute an intelligent energy-management system: flow networks, sensor networks, and sensitized objects [34]. A flow network "is a set of connected transport components that supports the movement of continuous matter (e.g., electricity, oil, air, and water)" [34]. Increasing the efficiency of flow networks is crucial to addressing sustainability goals, particularly as economic activities are energy-intense and produce high $\mathrm{CO}_{2}$ emissions [35]. A sensor network is "a set of spatially distributed devices that reports the status of a physical item or environmental condition" [34]. Technologies such as barcodes or radio-frequency identification (RFID) chips help the sensor network to provide the data used to optimize the functionality of the flow network [36]. A sensitized object is "a physical good that a consumer owns or manages, and has the capability to sense and report data about its use" [34]. As illustrated in Figure 1, an overarching IS brings these various elements together and forms an integrated solution. In this way, EI assumes an efficiency gain in the energy demand and supply system. Implementing EI requires a certain degree of intelligence that the IS must contribute [12]. Overall, the IS collects and transmits comprehensive data that are essential to optimizing algorithms and to providing relevant information to both the supply and demand sides [34]. 


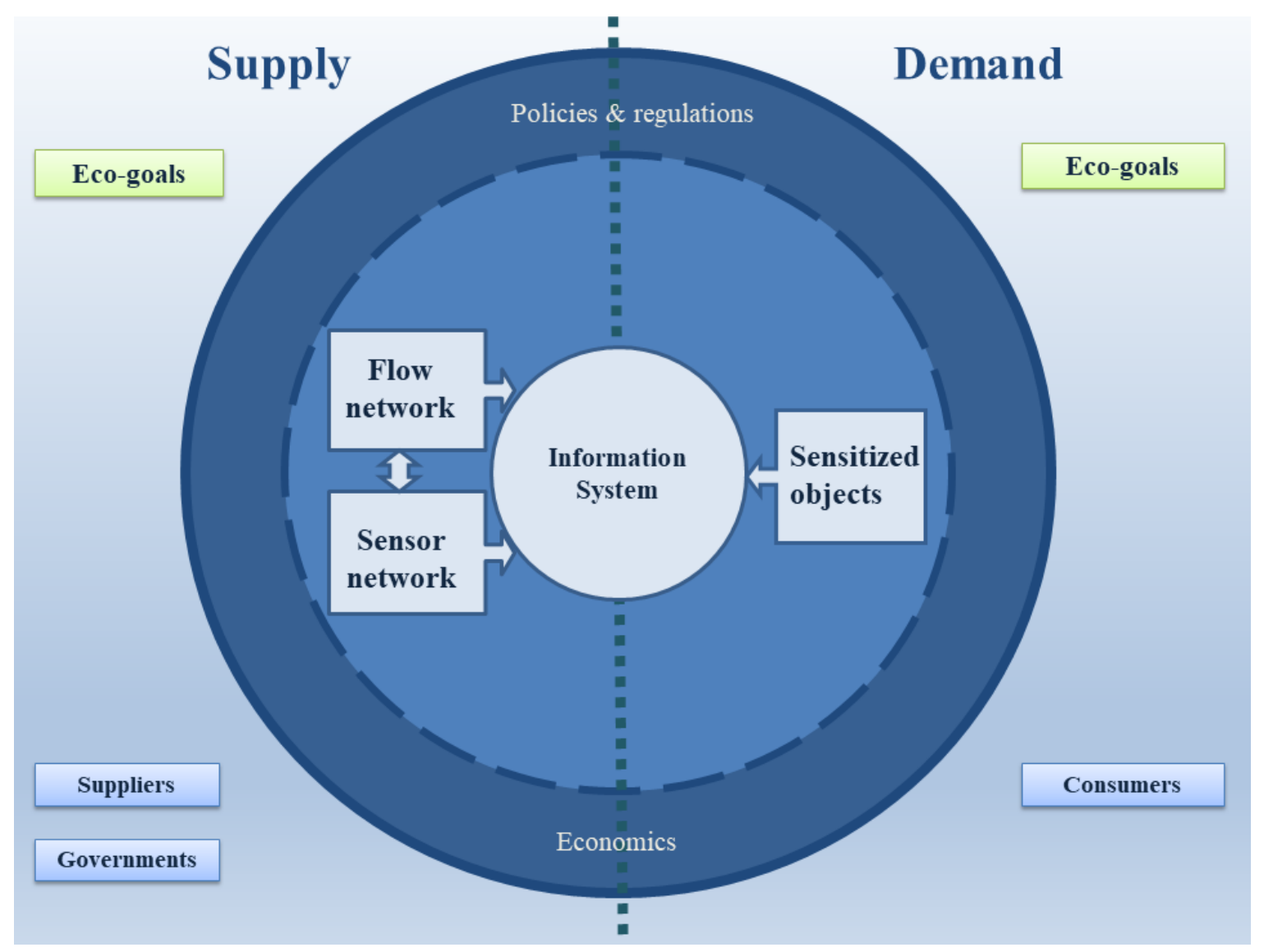

Figure 1. Energy Informatics (EI) framework. Representation based on [34].

\subsection{Community Innovation}

In the field of science and technology studies (STS), scholars use the sociological lens to study phenomena in the context of technology. Several innovation scholars drew from STS to understand technological innovation $[21,37,38]$. In this vein, researchers have taken an interest in the intertwined coevolution of technical and social developments in which a "community is part of the innovation itself" [38], and have coined the concept of community innovation and the related idea of configurational innovation. These scholars are interested in cases in which change in the social community itself is an integral part of the innovation. Three dimensions characterize community innovation. The first is the social dimension: [39] highlight the innovation happening outside of the changing existing devices and at the level of an "interplay of social, symbolic, and technological" innovations. The second is a collective operational mode [38], especially in the context of energy systems, "where users collectively arrange loosely related sets of components into local systems that work" [39]. The third is the technological component, which is the use of existing technologies with new technical and nontechnical work to achieve innovation in, for example, business models [39]. Following Reference [40], IS research also investigates the implications of interconnected processes and outcomes to better understand innovation management. In this context, business researchers expect a shift from the firm-centric innovation paradigm toward "webs of interdependence with partners" [41]. The implication of community innovation is to acknowledge its potential, constraints, and preconditions. The degree of cocreation depends on the level of community integration and activity patterns [42]. The co-ordination and the alignment of such a diverse group require constant stakeholder management. The social fabric of communities, that is, norms and shared ideology, influences the choice of goals and shapes the outcome [38]. 


\section{Case Description}

Our business case study setting is German energy company Energiequelle, which established an EI business model. Case company Energiequelle was chosen for the following reasons: First, Energiequelle succeeded in building Germany's first self-sufficient energy community and has since received increasing amounts of attention. Politicians and visitors from inside and outside Germany regularly visit the community and are guided through the facilities. Second, the setting of Energiequelle in the EI project of Feldheim is still relatively unique. Although there is growing interest in test beds in Germany, to the best of our knowledge, Feldheim is the only successful operational EI system in Germany. Third, the willingness of stakeholders to share experiences and knowledge allowed us to study the phenomenon of Energiequelle's EI strategy at multiple stakeholder levels, including those of Energiequelle's CEO and chief marketing officer; three people from the district and village government; the Climate Protection Officer of the Federal State of Brandenburg; one representative of the co-operative; two people from community management; two citizens of Feldheim; and two external experts who closely follow the Feldheim project. Altogether, we conducted 13 interviews. Each interview lasted between 30 and $60 \mathrm{~min}$ and was conducted in November 2015.

This business case study follows a practice-oriented research idea [43], deducting key insights, especially for high-level executives, policymakers, and society as a whole. Using a business case-study approach is justifiable, as the small number of EI cases in industrialized countries requires exploratory research design that allows us to obtain a general understanding before we seek quantitative evidence in future research [44]. Further, the interview approach facilitates studying the phenomenon from different levels of analysis, including the economic, social, and ecological levels [45], as well as takes the specific challenges of case-study research in small business and entrepreneurial scenarios into account [46].

The interviews were transcribed and partially translated. Using the EI framework, we analyzed the data with respect to Energiequelle's business strategy, the three different types of networks, the roles and relationships of all stakeholders, and the degree of fulfilment of ecogoals. To complement our interview data, the researchers collected and analyzed secondary data sources, such as Energiequelle's website and press releases, newspaper and magazine articles, information leaflets, and other available presentation material.

\section{Setting: An Energy Company at the Vanguard of Germany's Energy Transition}

In autumn 1993, Michael Raschemann, a civil-engineering student at the University of Applied Sciences in Potsdam, successfully presented his idea of building four wind turbines near Feldheim to a vestrymen meeting. More than two decades later, Raschemann is the CEO of Energiequelle, a leading German renewables company with more than 180 employees and an annual revenue of more than $€ 121$ million. What is even more impressive is that Energiequelle has succeeded in building Germany's first self-sufficient energy community. This system has 43 wind turbines, 284 solar panels, and a biomass plant.

The first four wind turbines in Feldheim were constructed from winter 1994 to spring 1995. From both a geographical and geological perspective, this choice is plausible. Feldheim and the surrounding area are in a wind-energy-friendly and tectonically useful location, including good relief, with a large amount of farmland and almost no forest. Raschemann successfully convinced the locals to realize this project. This first point of contact between Raschemann and local citizens laid the foundation for a trust-based relationship that was crucial for Energiequelle's project realization. Contrary to other cases where people demonstrate against infrastructure projects, the citizens of Feldheim were curious and open-minded from the start, and decided early on that they want a source of renewable energy in their community.

By 2006, Energiequelle had installed another 39 wind turbines during three construction phases in the Feldheim area. Throughout the entire period, Raschemann maintained a close relationship with the locals and local administration. This turned out to be a critical factor of the EI success. 
In 2008, the energy company started planning to build a solar-panel factory. Interestingly, this solarmodule factory could have been built in Treuenbrietzen, which is the district town; however, supported by local politicians, Energiequelle aimed to keep everything in the village, and so built the factory in Feldheim and supplied it with energy generated by the wind farm. Because solar-panel production facilities require a massive amount of heat, the energy company was looking for a sustainable solution and started planning to build a biomass plant. It soon became obvious that a collaborative effort with the local co-operative made sense for Energiequelle for the following reasons. The co-operative was under pressure because the prices of agricultural goods were falling and profitability was declining. The biomass plant therefore represented an opportunity for the co-operative. Agricultural output (e.g., corn) could be used as raw material in operating the plant. In addition, the biomass plant could supply the co-operative's facilities with sustainable and cost-efficient heat.

The joint realization of the biomass plant in autumn 2008 was mainly possible because of the considerable level of trust created between Energiequelle and the locals, whereby the needs of both the inhabitants and the co-operative were respected. At first, the heat grid only supplied the solar-panel factory, hall complex, and a pig farm with moderate heat. However, shortly after, the co-operative wanted to create heat transfer for one of their administrative buildings that was being renovated. During this time, Energiequelle recognized the potential of the business idea for intelligent heat transfer to the entire Feldheim community. Thus, Raschemann hosted the first of three meetings and explained the intentions of Energiequelle. He stated that those who would like to join are invited to declare their interest. Energiequelle representatives also had the idea that they could directly supply the properties of the villagers with wind energy in addition to heat. This occurred at a time of fluctuation in the energy market, when diesel fuel suddenly became as expensive as petrol at the gas station. This was an additional motivation that led to the second meeting, in which nearly all inhabitants of Feldheim participated. The idea for a bigger project grew out of this meeting. Thus, Energiequelle, the co-operative, and the locals planned a heat network for the entire village. "And this sense of a community has led us to where we are now" (CEO, Energiequelle).

During this planning phase, further support was received from the Federal State of Brandenburg, which was running a funding program at the time. From that program, Feldheim received funding for $50 \%$ of the heat network. With the third meeting, the company Feldheim Energie was founded. This entity, in which the locals also invested, was intended to manage the EI system in Feldheim that integrated electricity and heat. In autumn 2009, everything was prepared, and realization began. At that time, based on the initiative of Energiequelle, the participants also talked to the regional telecommunication provider about modernizing their cables, and to water providers about the water supply. The benefit was that they managed to co-ordinate these activities and realized it in one trench, which saved costs and gave the locals an edge. This was indeed a challenge. However, according to a Feldheim spokesperson, "it worked out, as all stakeholders were united" (spokesperson of Feldheim).

\section{Energiequelle's EI Business Model}

In Feldheim, Energiequelle designed and deployed an integrated energy production and consumption system comprising both electricity and heat management (see Figure 2). In our case company, we focus on the idea of a sustainable EI business model, with ecoefficiency, ecoequity, and ecoeffectiveness. Furthermore, the journey of Energiequelle proves the necessity of trust-based relationships between key stakeholders, namely, businesses, consumers, and the government, for the successful realization of EI projects. 


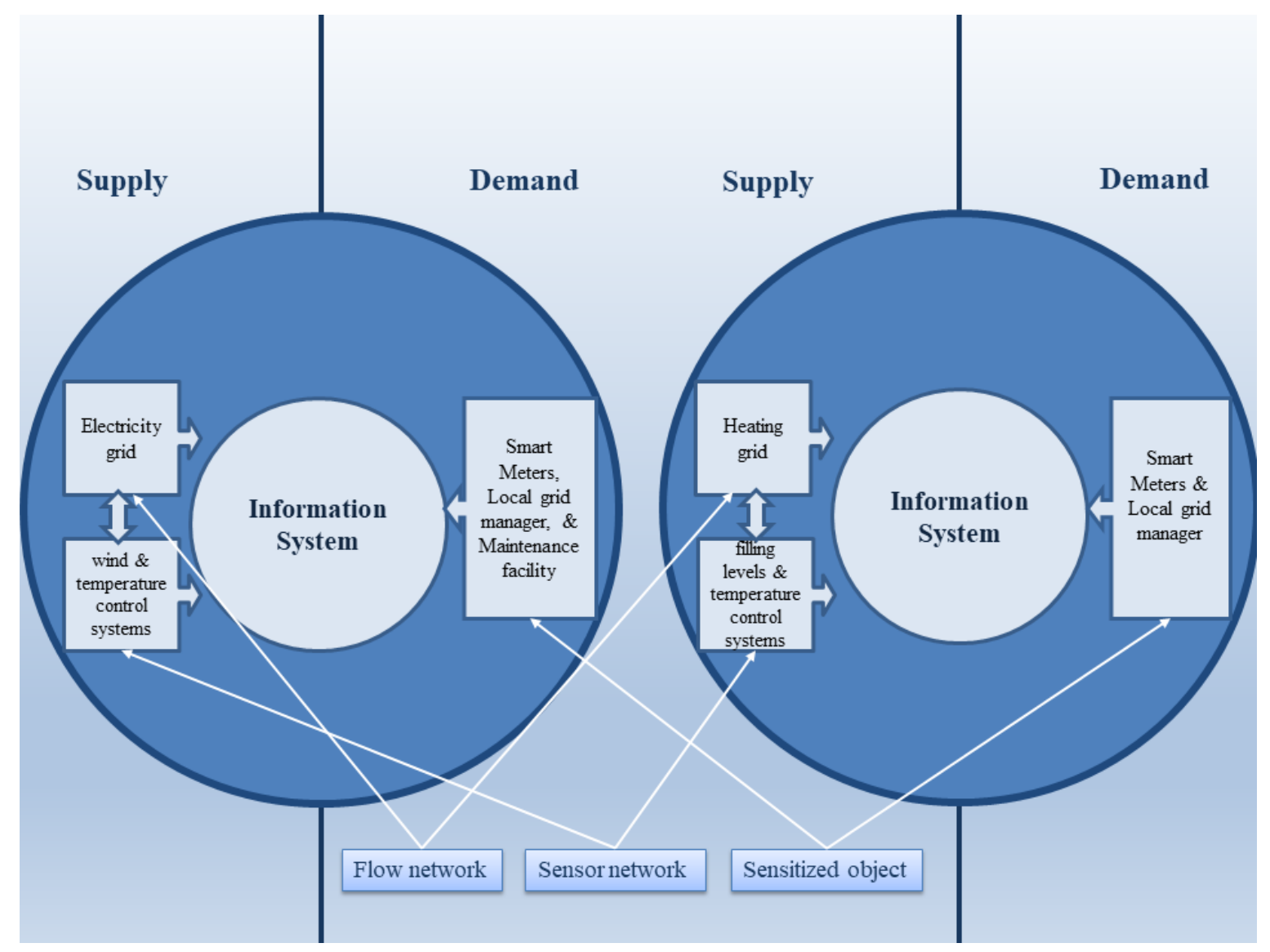

Figure 2. Elements of Energiequelle's EI framework. Representation based on [34].

The Feldheim system has two layers, electricity and heat. Both the electricity and heat grids are flow networks. The former directly connects the wind park to households and various facilities. To comply with regulatory issues and to avoid transit and tax collection, Energiequelle designed the system in such a way that Feldheim as a whole is plugged into the wind turbines. A new installation was necessary because the public energy provider was forced by German law to maintain supply possibilities and was not allowed to sell or rent their grid to the Feldheim community. The design of the heat grid is also quite peculiar. It connects the biomass plant, the solar-module factory, offices, the visitor center, the households, the flow heater (booster), which is required in low temperatures when the biomass process cannot work, and the pig farm.

Furthermore, there is a dense network of sensors and actuators that record wind velocities, outside temperatures, filling levels of biomass containers, and the temperatures of various biomass processes and the heating grid. All these data are fed into the IS and are essential for Energiequelle's optimal grid management.

With respect to sensitized objects, Energiequelle installed smart meters for heat and electricity in each household for monitoring and reporting consumption. These data are used twice. First, each household can assess its consumption on a web portal. Second, a citizen of Feldheim, given the title of local grid manager, who manages the heat network at a professional level, can assess the load profile of all consuming entities in Feldheim through their control panel, and thus regulate heating characteristics to manage peaks. For the electricity grid, Energiequelle has a maintenance facility where all production and consumption data are displayed on screens. As a reaction to demand changes or price changes at the jobbing house, the company can accordingly derate production volume.

The most crucial element in the EI system is the IS. This links the flows within and across the networks and sensitized objects and thus provides an integrated solution. In Energiequelle's setup, we identified various crucial functions of the IS. First, the smart grid requires intelligent heat 
management that levels differences in summer and winter. For example, there is the question of what to do with the heat in summer and, sometimes, the problem of where from to obtain heat in winter. When it suddenly becomes extremely cold, for example, $-20^{\circ} \mathrm{C}$, for a very long time, the biomass plant itself needs heat to maintain the biogas process at a certain temperature. This problem was solved by using the solar-module plant as a variable heat user and heat regulator, and to derate it remotely in times of high heating demand to ensure energy for households. When the cold wave passes, the heating is resumed. "It is something like an active storage we created" (CEO, Energiequelle).

Energiequelle's EI system in Feldheim is self-sufficient; however, it was designed with several backup entities to ensure supply reliability. Energiequelle equipped the system with a wood-chip heater and a flow heater powered by wind energy. These 350-kilowatt components are essential to ensure supply if other sources fail; however, activation of these components requires time and money. The wood-chip heater takes a while to reach the desired temperature and, when supplying energy, temperature takes equally long to decrease. Compared to the flow heater, for the wind-powered flow heater, the cost of one kilowatt hour is only one-third of the cost of one unit ( $€ 0.025$ compared to $€ 0.08)$. The main advantage of the flow heater is activation time. This component can supply heat almost instantaneously, with no follow-up time, residual heat, or warm-up phase, and it is therefore very important for ensuring high reliability for the entire EI system, especially in peak-demand scenarios.

Similar management processes are required to run the electricity grid. An intelligent system is needed because the wind farm feeds eight facilities. This ensures Feldheim is supplied with electricity and heat at all times, even if there is almost no wind. There are also times when Energiequelle must maintain the transformer station for the wind-turbine feed-two to three days a year-during which nothing works for eight hours and nothing is fed into the grid. For those times, there is an automatic switch to the biomass plant. All these grid-management considerations are essential to run this self-sufficient system, which is not connected to public providers.

Next to the biomass plant that serves as an electricity generator, Energiequelle realized a 10-megawatt storage facility, able to supply Feldheim for several days with heat and electricity. Today, the storage facility has the additional function of stabilizing the public grid, and only in the case of a power outage when the public grid is shut down does the storage facility run "black town capable" as an island that the consumers could check. Interestingly, a self-sufficient heat and electricity system ensures a much more secure supply, "which was not always there before" (spokesperson of Feldheim).

\subsection{Energiequelle Stakeholder Management}

In addition to the crucial role of an IS, our interview data show the importance of Energiequelle's stakeholder management (see Figure 3). Based on interviews with our case company, we provide evidence relating to the three most critical stakeholders, business, locals, and government. 


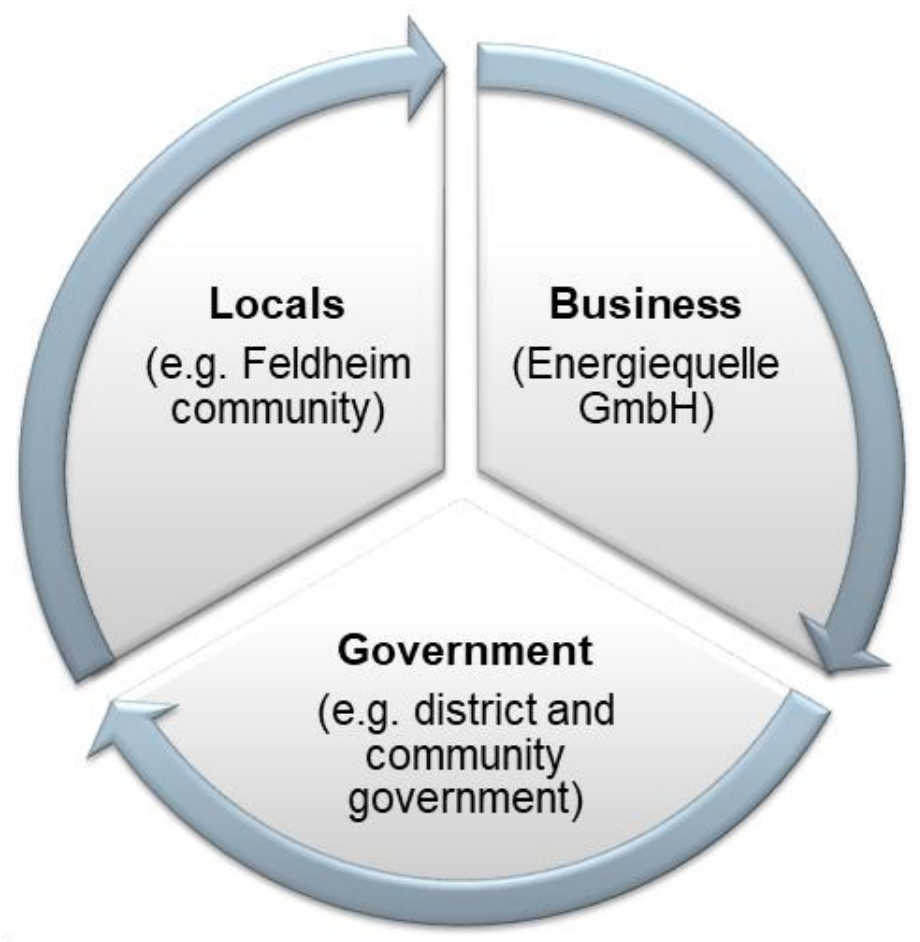

Figure 3. Key stakeholders in Energiequelle's EI project.

In the 1990s, when renewables were still in their infancy in Germany, Raschemann saw the possibilities of these technologies. However, it was not only his knowledge of technology and geology, but also his insistence on involving all stakeholders from the beginning, that made the difference: "He had a good way of presenting himself, [...] it was easy to trust him" (citizen of Feldheim). "The trust was there from the start" (spokesperson of Feldheim).

\subsubsection{Energiequelle}

The role of trust between all stakeholders in all stages of project realization has proven to be a critical element in the case of Energiequelle. Raschemann understood the importance of paying attention and listening. What makes people feel insecure about the project? Is it grounded in objectivity or is it rather a subjective notion? Further, he could sense curiosity in the village and found it important to communicate with the people, whether to address an imaginary issue or to deal with a real-world problem. In the long run, people's acceptance of an infrastructure project can be facilitated by including all stakeholders in the decision-making process $[20,47,48]$. "I think, this project would not have been possible, if we tried to plan it from top to bottom at the drawing board" (mayor of Treuenbrietzen). "Well, unity is very important in Feldheim, which is why everything worked out so well" (spokesperson of Feldheim).

\subsubsection{Co-Operative}

The co-operative plays a role in both the supply and demand sides of Energiequelle's journey. On the one hand, roughly $20 \%$ of the district is directly owned by the co-operative, making it a powerful voice in decision making. At the beginning of the entire project, the co-operative expressed concerns about Raschemann's ideas, as they feared a new competitor for land use. At that time, the market for agricultural products had also broken down, and prices steadily dropped. This was a result of the market opening due to the German reunification in 1990. At some point, the co-operative realized the potential to feed their crops and manure into the biomass process at the plant and to set up this new business. The organization also rented large amounts of land to Energiequelle and Feldheim Energie and thus generated a new revenue source. Thus, "the co-operative [...] were always an important 
partner, particularly because they hold the contracts for the area [...] and the usage rights and had to agree if we want to do something within those areas" (CEO, Energiequelle).

On the other hand, the co-operative is Energiequelle's heat and electricity customer. Agricultural processes are energy-intensive, especially in the digital age, and Energiequelle's project encouraged modernization of the co-operative's business model, and therefore the sustainability of agricultural business.

\subsubsection{Locals}

The inhabitants of Feldheim have a powerful sense of belonging to the village. While some communities are characterized by rifts or factions, the citizens in Feldheim view unity as being very important. Therefore, Energiequelle's decision to involve all stakeholders at the outset and to explain in detail all the steps and consequences was crucial for the overall success. "They were curious and open-minded and said, well, it's a new thing but we like it to happen here" (CEO, Energiequelle).

In retrospect, there was a certain momentum when Raschemann met the locals in Feldheim and presented his ideas. This early commitment of the citizens also helped to get Energiequelle's project started, and to convince the district administration to support EI in Feldheim. "The residents have also played a key role, as it came from the residents, not the politicians" (mayor of Treuenbrietzen).

In the case of Energiequelle, we identified communication as an important enabler of the relationship between actors. This mechanism turned out to be particularly relevant in implementing Energiequelle's EI system, which represented a drastic shift in a critical area of life-energy supply. "Wind engines were not well-known, perhaps from the coast, if at all; anyways, it was not common. Thus, the benefits and drawbacks were not known" (CEO, Energiequelle).

Communicating what would happen next and involving the locals was highly important. For example, Energiequelle organized cranes that helped citizens see the machine housing and the homeland from above. It also made clear the dimensions of the wind-turbine blades. To gain increased acceptance, Raschemann and his team organized inauguration ceremonies at each major stage of the project.

\subsubsection{District Government}

Finally, local government and administration played an accompanying role. As the energy market in Germany is highly regulated, a self-sufficient EI solution would not have been feasible without the support of the local administration. In many cases, particularly with infrastructure projects, any undertakings need to fit into bigger contexts that politicians frame in relation to regional development. The specific momentum of the Feldheim project and Raschemann's drive were so convincing that the district government "didn't care about fitting into some larger regional development plans or not" (mayor of Treuenbrietzen). Quite the opposite, they found that it "is a general requirement for energy transition to allow for innovative ways of design and deployment" (mayor of Treuenbrietzen).

\subsection{Energiequelle's Ecostrategy}

The case of Feldheim shows how Energiequelle considered sustainability goals, such as ecoefficiency, ecoequity, and ecoeffectiveness [49], in its EI system. Ecoefficiency is achieved with local citizens and firms paying about $20 \%$ below the average cost per energy unit. This reduced price is guaranteed by Energiequelle for at least 10 years, and compensates for shadows, noise, and decreased scenic beauty caused by the wind turbines. It also compensates for added costs as new energy grids were installed. From a business perspective, low energy prices are beneficial to Energiequelle, which runs local facilities and the visitor information center; the co-operative; and other local microfirms. Ecoefficiency is achieved through the intelligent management of different energy sources. Biomass energy is used as a basic heat source. In the case of peaks or very cold temperatures, heat is produced by the wood-chip plant. Finally, Energiequelle uses a wind energy-powered flow heater in situations of energy shortage. 
The costs per unit of wood-chip energy and flow-heater energy are twice and eight times higher, respectively, than the cost of heat produced by the biomass plant.

Energy transitions should include energy equity considerations [50]. Energiequelle's business case shows that ecoequity should ensure a fair distribution of resources [51]. Feldheim proves that all affected stakeholders should be included; for example, we need to provide relief to those who carry the burden of having wind turbines and biomass plants in their backyards. This relief can be in the form of lower costs, that is, locals pay a significantly lower price for each energy unit. Additionally, locals should benefit in the form of modernized infrastructure, such as roads and street lighting, or in the form of educational or social aspects, such as local kindergartens, clubs, or space for local festivals.

Ecoeffectiveness assumes a massive shift in terms of people's mindset [52]. Energiequelle's idea of a self-sufficient EI solution is a possible concept for future energy systems based on renewable sources. Such a concept requires an elevated level of acceptance by those directly affected by its negative aspects, as well as compensation, such as lower electricity prices. A trust-based relationship between the involved actors further encourages the commitment of the locals to the entire transformation.

\section{Lessons Learned}

Six lessons can be inferred from Energiequelle's EI business model in Feldheim and can help CEOs and CBDOs of other energy companies set up business models that take advantage of the benefits of EI.

\section{Lesson 1: Identify and Exploit Business Models for EI}

Utilities consider the emergence of local and sustainable grid solutions as a huge threat to their own business [53]. However, as the journey of Energiequelle has shown, focusing on and providing energy systems based on EI can be more than a remedy. As such, EI can become a core business asset of energy companies [54,55].

This could quickly become highly important for energy-supply companies amid nuclear-power phase-outs and decreasing profits from fossil-fired power stations due to several reasons. First, climate-protection regulations are increasingly challenging the operation of these types of power plants and cost energy suppliers money. Second, the cost of producing each unit of energy from renewable-energy sources, like wind turbines and solar collectors, approaches zero over time after accounting for fixed costs, such as research and development and deployment [6]. Consequently, consumer energy prices will decline once the transition from fossil-energy sources to renewables has progressed. Third, outdated transmission grids, like those in Germany, and the lack of legacy transmission infrastructures in many large Western economies like the United States both create opportunities to deploy renewable-energy storage systems; these can take shape as EI systems that serve remote local communities and function as critical infrastructure in urban areas. EI business models offer the chance to deliver sustainable energy to people around the world, even in developing countries [56].

By following Energiequelle's journey, we give further evidence for potentially new revenue streams in the context of EI, and provide proof of concept. The key areas for revenue streams are: design, infrastructure, deployment, management, control, and maintenance (see Table 1).

Table 1. Key areas for revenue streams of the EI business model.

\begin{tabular}{cc}
\hline Revenue Stream & Description \\
\hline Design & $\begin{array}{c}\text { The modular and flexible architecture of EI systems allows the individual and } \\
\text { case-specific optimization of flow networks, sensor networks, and sensitized objects. } \\
\text { Manufacturing and assembling EI system components like generators and panels } \\
\text { (heat and power, solar), storage systems, load controllers, inverted relays, controller } \\
\text { platforms, and vehicle chargers. }\end{array}$ \\
\hline
\end{tabular}


Table 1. Cont.

\begin{tabular}{cc}
\hline Revenue Stream & Description \\
\hline Deployment & $\begin{array}{c}\text { Installation and configuration of components and systems. } \\
\text { Integration into customized working systems. } \\
\text { Testing (test plans and procedures) and certification. } \\
\text { Applying Information System (IS). } \\
\text { Management } \\
\text { Secure backup power. } \\
\text { Control and } \\
\text { Maintenance }\end{array}$ Provision of ongoing operational control and maintenance of EI systems and equipment. \\
\hline
\end{tabular}

Active companies in the energy market should take the chance to put themselves in a digitized and renewables-driven framework. Opportunities for EI would also attract players from other industries. The number of application fields and potential customers is constantly increasing (see Lesson 2). CEOs and CBDOs need to harmonize the technical and organizational design potential of EI with suitable contract proposals and pricing models for customers that allow for individual price setting. Customers or firms that need high reliability in their power supply should be charged higher prices for their solution than customers with a less-critical dependency on gapless power. In this regard, we see IS as a key facilitator for the introduction of demand-response systems, smart meters, and other forms of telematics.

\section{Lesson 2: Address Niche Customers First and Provide Individual Solutions}

The second case-related lesson involves the approach that EI providers should follow. We see good chances to dive into this business by addressing niche customers with specific needs and grid requirements first. As we have seen in our study, the CEO of Energiequelle was looking for an appropriate area for wind-energy production. He quickly realized that designing the Feldheim grid in a way that suited the specific needs of Feldheim citizens was a key factor in its implementation and success.

For energy companies, small-sized communities in remote areas could be the first customer segment for the installation of EI systems. This idea makes sense because wind- and solar-power plants need considerable land area; integration in rural areas is much easier than in bigger cities for this reason. More importantly, deploying local EI systems does not require maintaining large overland grids that connect power plants with remote areas. Applying EI would also avoid discussions and costs to energy providers related to the installation of more (and even larger) overland lines. If we would follow an approach in which the energy system is divided into parcels, each parcel could be designed to suit the specific needs of citizens and industries. Further, local geological and meteorological conditions could be considered in the design and deployment phase of EI systems. Of course, various backup "circles" of energy supplies (e.g., biogas and battery systems) are required to ensure reliable and quality supply. The case of Energiequelle shows that EI solutions are even cheaper than prevalent ones.

Other application fields are critical services. Industrial parks benefit from the individual design and deployment opportunities presented by local EI systems. Like the community framework, energy-supply and -management systems can serve customer needs very well. In a similar case, operating server farms or data centers often requires specific energy-supply configurations, in which energy companies can charge high premiums to ensure reliability. Although these solutions induce very high costs for the operators of those farms or centers, the opportunity for an individual design is a huge benefit. Local EI systems help remove barriers to operating in remote areas. In this way, big farms or data centers can be in less urbanized areas because a locally designed EI system would not necessarily need a connection with overland grids.

Put simply, EI-based business models can service specific customer needs more effectively than one-size-fits-all solutions. This is particularly essential when power outages are strongly linked to production losses, productivity decrease, or even lost company sales. In these cases, EI-based 
systems can be designed to be extremely secure and resilient in periods of critical loads or cyberattacks. The latter issue is particularly relevant in the context of digitized and interconnected infrastructures. Finally, local DRM further increases energy-consumption efficiency and, consequently, energy equality.

Lesson 3: Inspire Locals and Jointly Realize Projects

Energy companies need to engage with all stakeholders. Generally, infrastructure projects that imply significant technological and societal change require the involvement of all stakeholders from the beginning [57]. In this regard, Energiequelle's strategy in Feldheim is an ideal example: the early integration of stakeholders, locals, regional governments, and local firms, was a key facilitator of acceptance, implementation, and success. The CEO of Energiequelle communicated with the citizens from the outset and discussed plans with all interest groups. He rapidly recognized their expectations about their village and future, and made them part of the entire solution. In addition, revealing financial planning was as useful as the direct financial participation of the citizens. It is essential to uncover what requirements or characteristics matter most to them: reliability, control, security, cost, or something else [19]. Finally, the added value in the case of the Energiequelle's EI system was the long-term agreement between the community and Energiequelle. In this regard, Raschemann offered long-term participation and benefits to the locals.

In addition to increased acceptance and success rates, completing the project in collaboration with local stakeholders creates a direct supplier-customer link because of the long-term agreement that usually follows the initial investment and deployment phase. Using this tool, energy suppliers have the chance to ensure customer retention. EI business models thus offer the chance to reduce loss of clients that often occurs after the liberalization of markets. Consequently, we believe that Energiequelle's holistic approach to future energy policy could best balance needs and concerns of all interest groups. In a similar vein, energy production and consumption should not be discussed as a single sector issue, but as something that crosses many disciplines [13].

Lesson 4: Provide Proof of Concept and Secure Energy Equity

Energiequelle's journey provides proof of concept for the idea of EI in future energy production. We learned from Energiequelle that technical realization is not a major challenge. What we need to promote is the diffusion of this solution and more cases of successful implementation. Specific focus needs to be placed on acceptance issues because energy transition induces technological and societal change.

We recommend that companies act quickly. Energiequelle's journey has received significant attention from policymakers, businesses, and the public. We assume that energy suppliers that enter this market early would gain greater profit than latecomers. A higher number of successfully realized projects would build more interest and trust. Consequently, we expect demand for this solution from other local communities, and critical services like educational campuses, hospitals, and data centers, to increase.

From a societal perspective, sustainable solutions based on renewables go hand in hand with international and national climate-protection goals. In this regard, we expect further support from governments and policy for EI diffusion. Avoiding huge overland lines reduces the cost of energy transitions, and lessens public concern and resistance to new energy technologies.

Lesson 5: Islanding Ensures Reliability of Supply and Specific Energy Solutions for Local Communities and Critical Services

From our study, we can infer that islanding not only ensures energy supply in remote areas but, even more interestingly, also exploits the opportunities of renewable-energy sources. Regarding the former, we believe that Energiequelle's EI systems are a resilient solution for energy management in rural areas. This is especially important against the backdrop of an increasing number of natural disasters, such as in North America, Asia, and Europe. The more remote an area is, the higher the requirements for overland grids are. Grids are often not robust, and are susceptible to errors 
and disasters. Local solutions do not require long wires to these areas and allow for individually designed solutions.

In the context of critical infrastructure, such as hospitals, military bases, and data centers, the design of EI systems offers individual solutions and possibilities in terms of reliability levels. We believe that microelements increase opportunities to set standards for supply security, and protection in case of force majeure. Further, in digitized and interconnected systems, such as smart cities or fully automated industrial facilities, local grids might decrease the risk of extensive blackouts due to cyberattacks or technical malfunctions. These events often cause lost production, reduced productivity, and reduced sales.

Additionally, Energiequelle's EI strategy fits the production and consumption patterns of renewables very well. Thus, production facilities for renewable-energy sources are decentrally located. Transferring energy over long distances results in considerable distribution losses. This problem is avoided if energy is locally produced. Furthermore, the avoidance of big overland wires reduces interference with nature and societal structures. New network infrastructure is only required if production and consumption sites are not in the same area. A centralized energy system would require connecting all parts of the country to a secure quality supply. Local grids would avoid these investments as energy mixes can be adjusted to local conditions.

\section{Lesson 6: Consider Civic Participation, as it Increases Acceptance of Innovative Technologies}

The final lesson we can take from Energiequelle's EI project relates to the effects of civic participation on infrastructure projects. Based on our findings, Energiequelle's approach increases the active participation of locals and, consequently, the acceptance of innovative infrastructure technologies. In our case, the local community felt they were part of the project. Consequently, the changing conditions during the transition were quickly accepted by the citizens and the realization of the infrastructure project supported.

Energy transition is a socioeconomic issue [42]. What we have learned from Energiequelle is that technical components and all dimensions of a successful EI solution based on renewables are not a problem. In addition to the economic incentives discussed earlier, it is the organizational change induced by the energy transition that requires specific attention [58]. Citizens need to accept and tolerate the innovative technological system, the new organization of energy supply, and their effects on daily life.

Interestingly, we find price incentives to be a complementary enabler of participation and acceptance. Energiequelle arranged energy unit costs that are $20 \%$ under the market price and fixed them for a period of 10 years. In addition to that, the citizens of Feldheim got the chance to make private investments in the project so that overall costs could be reduced. Our analysis revealed that, although the share of private investments was quite limited compared to the overall realization costs, the buy-in opportunity for citizens positively affected the participation and acceptance of the locals. We assume this commitment to be crucial for the overall success of Energiequelle's strategy.

An interesting secondary aspect is that the project has triggered energy consciousness among the citizens. We believe this to be essential to accomplish climate-protection goals. Reorganizing energy production through the implementation of EI is just one aspect. It is equally important that consumption patterns are adjusted to the production characteristics of renewables. As such, localized solutions with the direct participation of stakeholders exploit the potential of DRM, and help ensure appropriate peak management.

\section{Conclusions}

Limited fossil resources, government intervention, and decarbonization goals are forcing companies in the energy sector to rethink their business strategies. Transitioning to renewable-energy sources such as wind and solar not only induces technological change but also requires a reorganization of the entire energy market, including business models and stakeholder management. Recent discussions 
have shown that EI can be an appropriate way for energy companies to maintain their core business and generate additional revenue streams. However, sustainable EI business models for energy companies and their implementation are still in their infancy and require further proof of concept.

This business case study helps to provide proof of concept by describing how German energy company Energiequelle successfully applied EI for both electricity and heat at the community level. By tracking Energiequelle's journey, we (1) highlighted the crucial steps in establishing an EI-based microgrid, (2) identified strategies for the successful implementation of EI projects, and (3) discussed the vital role of effective stakeholder management. On the basis of our business case-study analysis, we present a suitable example of how the interplay between acceptance and participation can lead to the successful realization of infrastructure projects and, thus, the success of community-based innovation processes. Energy companies and policymakers should understand that consumers are also citizens of their city and are therefore interested in their local environment. Moreover, we present six lessons learned, including five key sources of future revenue streams for energy companies: design, infrastructure, deployment, management, and control and maintenance. We recommend companies to act quickly, as being the first in this market enables them to gain the greatest benefit from this business opportunity.

In addition, infrastructure projects that induce both technological and social change require a holistic approach to EI implementation. We encourage companies to engage in private-public partnerships to exploit financial opportunities and facilitate project approval procedure. Energiequelle's strategy shows how active co-operation with important stakeholders can facilitate the realization of an EI project. Interestingly, we identify private-investment opportunities as a complementary enabler of Energiequelle's project. This buy-in mechanism increases acceptance and success in the short run, and ensures customer retention in the long run.

\section{Limitations}

This work has several limitations. First, our study focused only on a single case company in Germany. Therefore, country-specific social and market structures must be taken into account when discussing strategic implications and drawing general conclusions [59]. Although the German energy market was liberalized in 1998, the sector is still highly regulated, particularly in the technical and organizational aspects [60]. Other country-specific aspects are an outdated infrastructure, rising costs of energy in the last decade, and extensive climate change discussions in society. In future research, scholars should extend our study to other countries with different institutional, industrial, and societal settings. Such research would provide further evidence of the potential of EI-based business models. Second, we framed the study around the EI business model that Energiequelle applied in Feldheim, and drew lessons from the level of energy companies. Future studies may go beyond the perspective of energy companies and executives within energy companies to that of information-technology (IT) executives and draw lessons from EI that IT executives in nonenergy industries need to know. By acknowledging these limitations, we discussed six strategically essential lessons that are associated with the approach of establishing the EI business model.

Author Contributions: Conceptualization, M.G.; data curation, M.G. and H.S.; formal analysis, M.G. and H.S.; methodology, M.G. and H.S.; project administration, H S. and T.S.; supervision, H.S. and T.S.; visualization, M.G.; writing—original draft, M.G.; writing—review and editing, M.G. and H.S.

Funding: This research received no external funding.

Acknowledgments: We would like to thank the editor of the journal as well as three anonymous reviewers for their valuable and helpful comments. Further, this paper has decisively benefitted from discussions with Shan L Pan and his great team. Finally, we acknowledge support by the German Research Foundation and the Open Access Publication Funds of TU Berlin.

Conflicts of Interest: The authors declare no conflict of interest. 


\section{References}

1. UNFCCC. United Nations Framework Convention on Climate Change. 2015. Available online: http:/ / unfccc. int/files/essential_background/convention/application/pdf/english_paris_agreement.pdf (accessed on 18 July 2018).

2. Chen, S.-C.; Hung, C.-W. Elucidating the factors influencing the acceptance of green products: An extension of theory of planned behavior. Technol. Forecast. Soc. Chang. 2016, 112, 155-163. [CrossRef]

3. Dagoumas, A.S.; Barker, T.S. Pathways to a low-carbon economy for the UK with the macro-econometric E3MG model. Energy Policy 2010, 38, 3067-3077. [CrossRef]

4. Energy UK. Pathways for the GB Electricity Sector to 2030. Full Report. 2016. Available online: https: / / www.energy-uk.org.uk/publication.html?task=file.download\&id=5722 (accessed on 18 July 2018).

5. Green, J.; Newman, P. Citizen Utilities: The emerging power paradigm. Energy Policy 2017, 105, $283-293$. [CrossRef]

6. Rifkin, J. The Zero Marginal Cost Society: The Internet of Things, the Collaborative Commons, and the Eclipse of Capitalism; Palgrave Macmillan: New York, NY, USA, 2014.

7. Mazzucato, M.; Semieniuk, G. Financing renewable energy: Who is financing what and why it matters. Technol. Forecast. Soc. Chang. 2018, 127, 8-22. [CrossRef]

8. Deloitte. 2018 Outlook on Power and Utilities. 2018. Available online: https://www2.deloitte.com/us/en/ pages/energy-and-resources/articles/power-and-utilities-industry-outlook.html (accessed on 18 July 2018).

9. Ochoa, R. Microgrids: why Small could be Beautiful for Electric Utilities. 2016. Available online: https:/ / www. accenture.com/us-en/blogs/blogs-microgrids-why-small-could-be-beautiful-electric-utilities (accessed on 18 July 2018).

10. Watson, R.T.; Boudreau, M.-C. Energy Informatics; Green ePress: Athens, GA, USA, 2011.

11. Watson, R.T.; Boudreau, M.-C.; Li, S.; Levis, J. Telematics at UPS: En Route to Energy Informatics. MIS Q. Exec. 2010, 9, 1-11.

12. Atzori, L.; Iera, A.; Morabito, G. The Internet of Things: A survey. Comput. Netw. 2010, 54, $2787-2805$. [CrossRef]

13. Gholami, R.; Watson, R.T.; Hasan, H.; Molla, A.; Bjørn-Andersen, N. Information Systems Solutions for Environmental Sustainability: How Can We Do More? J. Assoc. Inf. Syst. 2016, 17, 521-536. [CrossRef]

14. Disruptive Technology-Microgrid Market Potential. 2015. Available online: http://www.agrion.org/upload/ fichier/Emerging\%20Technologies\%20Perspectives\%20-\%20Microgrid.pdf (accessed on 18 July 2018).

15. Kranz, J.; Kolbe, L.M.; Koo, C.; Boudreau, M.-C. Smart energy: Where do we stand and where should we go? Electron. Mark. 2015, 25, 7-16. [CrossRef]

16. Malhotra, A.; Melville, N.P.; Watson, R.T. Spurring Impactful Research on Information Systems for Environmental Sustainability. MIS Q. Exec. 2013, 37, 1265-1274. [CrossRef]

17. Meehan, B.; New Energy Sources Challenge Utilities to Innovate. Geospatial World Blog. Available online: https:/ / www.geospatialworld.net/blogs/new-energy-sources-challenge-utilities-to-innovate/ (accessed on 6 January 2019).

18. Wolsink, M. The research agenda on social acceptance of distributed generation in smart grids: Renewable as common pool resources. Renew. Sustain. Energy Rev. 2012, 16, 822-835. [CrossRef]

19. Spiess, H.; Lobsiger-Kägi, E.; Carabias-Hütter, V.; Marcolla, A. Future acceptance of wind energy production: Exploring future local acceptance of wind energy production in a Swiss alpine region. Technol. Forecast. Soc. Chang. 2015, 101, 263-274. [CrossRef]

20. Yun, S.; Lee, J. Advancing societal readiness toward renewable energy system adoption with a socio-technical perspective. Technol. Forecast. Soc. Chang. 2015, 95, 170-181. [CrossRef]

21. Strengers, Y. Smart Energy Technologies in Everyday Life: Smart Utopia? Springer: New York, NY, USA, 2013.

22. Deakin, M.; Al Waer, H. From intelligent to smart cities. Intell. Build. Int. 2011, 3, 140-152. [CrossRef]

23. van der Horst, D. NIMBY or not?: Exploring the relevance of location and the politics of voiced opinions in renewable energy siting controversies. Energy Policy 2007, 35, 2705-2714. [CrossRef]

24. Zott, C.; Amit, R. Business Model Design: An Activity System Perspective. Long Range Plan. 2010, 43, $216-226$. [CrossRef]

25. Hienerth, C.; Keinz, P.; Lettl, C. Exploring the Nature and Implementation Process of User-Centric Business Models. Long Range Plan. 2011, 44, 344-374. [CrossRef] 
26. Teece, D.J. Business Models, Business Strategy and Innovation. Long Range Plan. 2010, 43, 172-194. [CrossRef]

27. Schneider, S.; Spieth, P. Business Model Innovation: Towards and Integrated Future Research Agenda. Int. J. Innov. Mgt. 2013, 17, 1340001. [CrossRef]

28. Markides, C. Disruptive Innovation: In Need of Better Theory*. J Prod. Innov. Man 2006, 23, 19-25. [CrossRef]

29. Baden-Fuller, C.; Mangematin, V. (Eds.) Business Models and Modelling; Emerald: Bingley, UK, 2015.

30. Chesbrough, H. Business Model Innovation: Opportunities and Barriers. Long Range Plan. 2010, 43, 354-363. [CrossRef]

31. Demil, B.; Lecocq, X. Business Model Evolution: In Search of Dynamic Consistency. Long Range Plan. 2010, 43, 227-246. [CrossRef]

32. Koen, P.A.; Bertels, H.M.J.; Elsum, I.R. The Three Faces of Business Model Innovation: Challenges for Established Firms. Res. Technol. Manag. 2015, 54, 52-59. [CrossRef]

33. Gomes, L.A.d.V.; Facin, A.L.F.; Salerno, M.S.; Ikenami, R.K. Unpacking the innovation ecosystem construct: Evolution, gaps and trends. Technol. Forecast. Soc. Chang. 2016. [CrossRef]

34. Watson, R.T.; Boudreau, M.-C.; Chen, A.J. Information Systems and Environmentally Sustainable Development: Energy Informatics and New Directions for the IS Community. MIS Q. 2010, 34, 23-38. [CrossRef]

35. Hoffert, M.I.; Caldeira, K.; Benford, G.; Criswell, D.R.; Green, C.; Herzog, H.; Jain, A.K.; Kheshgi, H.S.; Lackner, K.S.; Lewis, J.S.; et al. Advanced technology paths to global climate stability: Energy for a greenhouse planet. Science 2002, 298, 981-987. [CrossRef] [PubMed]

36. Akyildiz, I.F.; Su, W.; Sankarasubramaniam, Y.; Cayirci, E. A survey on sensor networks. IEEE Commun. Mag. 2002, 40, 102-114. [CrossRef]

37. Hyysalo, S.; Usenyuk, S. The user dominated technology era: Dynamics of dispersed peer-innovation. Res. Policy 2015, 44, 560-576. [CrossRef]

38. Van Oost, E.; Verhaegh, S.; Oudshoorn, N. From Innovation Community to Community Innovation: User-initiated Innovation in Wireless Leiden. Sci. Technol. Hum. Values 2008, 34, 182-205. [CrossRef]

39. De Vries, G.W.; Boon, W.P.C.; Peine, A. User-led innovation in civic energy communities. Environ. Innov. Societal Transit. 2016, 19, 51-65. [CrossRef]

40. Nambisan, S.; Lyytinen, K.; Majchrzak, A.; Song, M. Digital innovation management: Reinventing innovation management research in a digital world. MIS Q. 2017, 41, 223-238. [CrossRef]

41. Tushman, M.; Lakhani, K.R.; Lifshitz-Assaf, H. Open Innovation and Organization Design. J. Organ. Des. 2012, 1, 24-27.

42. Russell, M.G.; Smorodinskaya, N.V. Leveraging complexity for ecosystemic innovation. Technol. Forecast. Soc. Chang. 2018. [CrossRef]

43. Dul, J.; Hak, T. Case Study Methodology in Business Research, 1st ed.; Butterworth-Heinemann: Oxford, UK, 2007.

44. Yin, R.K. Case Study Research: Design and Methods, 5th ed.; Sage Publications: Thousand Oaks, CA, USA, 2014.

45. Pan, S.L.; Tan, B. Demystifying case research: A structured-pragmatic-situational (SPS) approach to conducting case studies. Inf. Organ. 2011, 21, 161-176. [CrossRef]

46. Perren, L.; Ram, M. Case-study method in small business and entrepreneurial research: Mapping boundaries and perspectives. Int. Bus. J. 2004, 22, 83-101. [CrossRef]

47. Watson, R.T.; Corbett, J.; Boudreau, M.C.; Webster, J. An information strategy for environmental sustainability. Commun. ACM 2012, 55, 28-30. [CrossRef]

48. Seyfang, G.; Hielscher, S.; Hargreaves, T.; Martiskainen, M.; Smith, A. A grassroots sustainable energy niche?: Reflections on community energy in the UK. Environ. Innov. Societal Transit. 2014, 13, 21-44. [CrossRef]

49. Dyllick, T.; Hockerts, K. Beyond the business case for corporate sustainability. Bus. Strat. Env. 2002, 11, $130-141$. [CrossRef]

50. vom Brocke, J.; Watson, R.; Dwyer, C.; Elliot, S.; Melville, N. Green Information Systems: Directives for the IS Discipline. Available online: http:/ / aisel.aisnet.org/cais/vol33/iss1/30 (accessed on 6 January 2019).

51. Gladwin, T.N.; Kennelly, J.J.; Krause, T.-S. Shifting Paradigms for Sustainable Development: Implications for Management Theory and Research. Acad. Manag. Rev. 1995, 20, 874-907. [CrossRef]

52. McDonough, W.; Braungart, M. Cradle to Cradle: Remaking the Way We Make Things; North Point Press: New York, NY, USA, 2002.

53. Stephens, J.C.; Kopin, D.J.; Wilson, E.J.; Peterson, T.R. Framing of customer engagement opportunities and renewable energy integration by electric utility representatives. Util. Policy 2017, 47, 69-74. [CrossRef] 
54. Schuelke-Leech, B.-A.; Barry, B.; Muratori, M.; Yurkovich, B.J. Big Data issues and opportunities for electric utilities. Renew. Sustain. Energy Rev. 2015, 52, 937-947. [CrossRef]

55. Agüero, J.R.; Khodaei, A. Roadmaps for the Utility of the Future. Electr. J. 2015, 28, 7-17. [CrossRef]

56. Kishita, Y.; McLellan, B.C.; Giurco, D.; Aoki, K.; Yoshizawa, G.; Handoh, I.C. Designing backcasting scenarios for resilient energy futures. Technol. Forecast. Soc. Chang. 2017, 124, 114-125. [CrossRef]

57. Gurău, C.; Dana, L.-P. Environmentally-driven community entrepreneurship: Mapping the link between natural environment, local community and entrepreneurship. Technol. Forecast. Soc. Chang. 2018, 129, 221-231. [CrossRef]

58. Verbong, G.P.J.; Beemsterboer, S.; Sengers, F. Smart grids or smart users?: Involving users in developing a low carbon electricity economy. Energy Policy 2013, 52, 117-125. [CrossRef]

59. Harrison, R.T.; Leitch, C. Voodoo Institution or Entrepreneurial University?: Spin-off Companies, the Entrepreneurial System and Regional Development in the UK. Reg. Stud. 2010, 44, 1241-1262. [CrossRef]

60. Renn, O.; Marshall, J.P. Coal, nuclear and renewable energy policies in Germany: From the 1950s to the "Energiewende". Energy Policy 2016, 99, 224-232. [CrossRef]

(C) 2019 by the authors. Licensee MDPI, Basel, Switzerland. This article is an open access article distributed under the terms and conditions of the Creative Commons Attribution (CC BY) license (http:/ / creativecommons.org/licenses/by/4.0/). 